\title{
Developing Sustainability Indicators for Higher Education Institutions in Taiwan
}

\author{
Wen-Sheng Wang and Gregory S. Ching
}

\begin{abstract}
Higher education institutions are organizations that are crucial to the society. Being considered as a public good, hence, being sustainable is an important issue. This paper shall attempt to discuss the development of the sustainability indicators meant for higher education institutions. This presentation focuses the discussion on sustainability indicators developed mostly in the North America, Europe, and Taiwan. In addition, the sustainability tracking assessment and rating system (STARS) are also analyzed for items that are relevant to the higher education institutions in Taiwan. Lastly, the study shall contribute to the idea that maintaining a green sustainable institution for future generation is a must in the higher education institutions of today.
\end{abstract}

Index Terms - Sustainability, indicators, higher education institutions, literary review, educational policy.

\section{INTRODUCTION}

Recent issues within the higher education institutions in the West are much focused on the concerns with the overall impact of the economy and society to environment. Much information and strategic initiatives are related to environmental protection, while gathering of indicators in measuring such sustainability factors are considered crucial. Recently, many mentioned that the periodic measurements regarding the implementation and evaluation of industries, organizations, and institutes of learning within the areas of sustainability should be explored. In Taiwan, industries have also been undergoing intensive competition, more so with the higher education institutions. Hence, the Taiwan Ministry of Education has started a series of campaigns toward a green campus environment [1].

In the beginning of 2009, Taiwan higher education institutions have been trying to adopt a green school strategy. However, an appropriate assessment tool is yet to be developed. Some argued that education is the emerging monetary of opportunity. Hence, the higher education institutes need to change and become sustainable [2]. The focus of this paper is to provide the background concepts regarding the development of sustainability indicators for higher education institutions in Taiwan. In addition, this study also seeks to understand the various underlying factors that contribute to the sustainable development of higher education institutions in Taiwan. It considered that education

Manuscript received May 20, 2014; revised August 18, 2014. This work was supported in part by the Taiwan Ministry of Science and Technology under Grant 102-2410-H-262-012-SS2.

W.-S. Wang is with the National Central University, Taiwan (e-mail: vincenwan@hotmail.com).

G. S. Ching is with the Graduate School of Educational Leadership and Development, Fu Jen Catholic University, Taiwan (e-mail: gregory_ching@yahoo.com). is the foundation for making opportunities happen, hence, being a public good, a sustainable institute shall act as a key role that leads to a better opportunity for people.

\section{Sustainable Development}

The most frequently cited definition of sustainability comes from the report of the World Commission on Environment and Development, which note the introductions of different directions for "our common future". Sustainable development therefore is simply defined as the "development that meets the needs of the present without compromising the ability of future generations to meet their own needs" [3]. In addition, within the many United Nations' conferences and Non-Governmental Organizations meetings during 1990s, its meaning have since developed into a significant framework concerning the meaning and implications of sustainability [4].

In light of these leading international events, the resulting issues have noted various agreements, such as the Vienna Conference Tribunal on Violations of Women's Human Rights, Agenda 21 from the United Nations Conference on Environment and Development in Rio, the Copenhagen Social Summit discussions of equitable, and "people-centered" development, just to name a few. These international agreements have since been the underlining policy directions for a sustainable higher education institution [4].

To understand better, a so-called sustainable college or university (or higher education institution) would focus on the following concepts, such as its curriculum and research, students as a global citizen, environmental consciousness, and many others. More importantly, the school would operate as a sustainable community, perform responsible consumption of energy, water, and would consider how to take care of waste, emission, food, while supporting sustainable development in neighbor and immediate community. Therefore, educational institutions must contribute to achieve the goal in sustainability development.

According to the United Nations Educational, Scientific and Cultural Organization (UNESCO) Agenda 21; a much anticipated educational issue, UNESCO demonstrated the issue of sustainable development as part of a larger sustainable development topic [5]. Hence, this study emphasizes the definition related to sustainable development generated for the higher educational institutions. These may refer to the states of international agreements or declarations and organizations that are able to enhance schools towards future success. The following section will then discuss in brief the following: The Brundtland Commission report of 1987, The Talloires Declaration-10 Point Action Plan, 
Halifax Action Plan, the Association of University Leaders for a Sustainable Future, the Association for the Advancement of Sustainability in Higher Education, and the Taiwan Sustainable Campus project.

\section{A. The Brundtland Commission Report of 1987}

The Brundtland Commission organized by the United Nations in 1983 and considered the mission related to anthropogenic events on the global environment. The Brundtland Commission Report issued in 1987, and it requested a greater international cooperation to promote global issues concerning environmental, economic, and social sustainability. The report indicated the various environmental problems closely associated with the problems of economic and social inequality. It also demonstrates a frequently illustrated definition of the term "sustainable development", describing that, "sustainable development is a development that meets the needs of the present without compromising the ability of future generations to meet their own needs" [6].

The Brundtland Commission Report is also concerned with that of the human resource development within the aspect of poverty reduction, gender equity, and wealth redistribution; which was essential to formulating ways for environmental conservation and it is recognized as the environmental limits to economic growth. However, the Report was unavailable to confirm the production and responsibility for environmental degradation, which might be cause due to the shortage of analyzing the principles of the market and economic growth. This shortage simultaneously resulted in a misunderstanding of the terms of sustainable development.

\section{B. The Talloires Declaration - 10 Point Action Plan}

The Talloires Declaration developed in Talloires, France during the international conference in 1990. This is the first official proclamation made by presidents, chancellors, and rectors of university, the proclamation concerning a commitment to environmental sustainability in higher educational institutes. The Talloires Declaration including a ten-point action plan for affiliating sustainability and environmental feature related to teaching, research, operations and outreach in colleges and universities. It has simultaneously been signed by over 400 university chief leaders in over 50 countries. The ten-point action plan describes as follow: Increase awareness of environmentally sustainable development; Create an institutional culture of sustainability; Educate for environmentally responsible citizenship; Foster environmental literacy for all; Practice institutional ecology; Involve all stakeholders; Collaborate for interdisciplinary approaches; Enhance capacity of primary and secondary schools; Broaden service and outreach nationally and internationally; and Maintain the movement [7].

\section{Halifax Action Plan}

The presidents of universities from Canada, Brazil, Indonesia, Zimbabwe, and many other countries gathered for the conference on "Creating a Common Future" consistently strived for a sustainable future at Halifax, Canada, during the December of 1991. The meeting focuses on the environmental issue regarding sustainable development emphasized as well as by the senior representatives of the United Nations University, the International Association of Universities, the Association of Universities and Colleges of Canada. The Halifax meeting aims to the sustainable issue calls for the contribution of all universities to the following actions [8]: 1) To ensure that the voice of the university be clear and uncompromising in its ongoing commitment to the principle and practice of sustainable development within the university, and at the local, national and global levels; 2) To utilize the intellectual resources of the university to encourage a better understanding on the part of society of the inter-related physical, biological and social dangers are facing the planet Earth; 3) To emphasize the ethical obligation of the present generation to overcome those current malpractices of resource utilization and those widespread circumstances of intolerable human disparity which lie at the root of environmental unsustainability; 4) To enhance the capacity of the university to teach and practice sustainable development principles, to increase environmental literacy, and to enhance the understanding of environmental ethics among faculty, students, and the public at large; 5) To cooperate with one another and with all segments of society in the pursuit of practical capacity-building and policy measures to achieve the effective revision and reversal of those current practices which contribute to environmental degradation, to South-North disparities and to inter-generational inequity; and 6) To employ all channels open to the university to communicate these undertakings to UNCED, to governments and to the public at large.

\section{Association of University Leaders for a Sustainable Future}

The Association of University Leaders for a Sustainable Future (ULSF) is the Secretariat for signatories of the Talloires Declaration in 1990. This declaration has been signed by over 400 presidents and chancellors in worldwide college and university. The association including universities and colleges in worldwide countries summarize as follow: United States, Australia, Canada, Finland, Japan, Mexico, Ireland, Spain, New Zealand, Portugal, Hong Kong, India, and United Kingdom [9]. ULSF supports sustainability focus on teaching, research, operations and outreach in higher educational institutes through publications, research, and evaluating tool.

ULSF encourage higher educational institutes to conduct in education, research, policy formation, and information exchange concerning population, environment, and sustainable development enhance a sustainable future. It also contributes as the Secretariat for signatories of the Talloires Declaration, the members participated in constant programs and responsibly consulting to support sustainability in higher educational institutes includes: 1) Research and consulting on effective strategies for "greening" institutional practices, policies, and teaching; 2) Organizational change and social learning for sustainability; 3) Implementation of the Talloires Declaration and other institutional commitments to green the campus and cut greenhouse gas emissions; 4) Campus sustainability assessment; 5) Implementing humane and 
sustainable food systems; and 6) Research and consulting on implementing the UN Decade of Education for Sustainable Development and creating and evaluating UN Regional Centers of Excellence.

\section{E. The Association for the Advancement of Sustainability in Higher Education (AASHE)}

AASHE is an association of colleges and universities in United States and Canada, which advocated creating a sustainable future for higher educational institutes. It was founded in 2006 with a vision to reach sustainability in all fields of higher educational institutes. The dimensions of evaluating sustainability are education and research, operation, and planning, administration, and engagement depicts the factors including curriculum, outreach, governance and operations, and others involved education, communication, research, and professional development [10].

AASHE contributes to create an advancing sustainability in higher education institution; it also provides administrators, faculty, staff, and students with essential knowledge and resources. It also provides remarkable chances for the development and created sustainability initiative. Furthermore, AASHE considers higher education institutions should play an important role to ensure people to have an understanding of the issue of environmental, social, economic and sustainability challenges. It acts a key role as a thought leader for higher education sustainability.

AASHE promotes the goal related to sustainable development as follow description [11]: 1) Deliver services that increase its value to a growing and diverse membership and will increase its impact on sustainability in higher education; 2) Convene experts and collect, evaluate, and disseminate information and tools to increase the understanding of sustainability and its relevance to higher education stakeholders; 3) Support and enable higher education to reduce greenhouse gas emissions and to adapt to the impacts of global climate disruption; 3) Lead the transformation of educational practices (including the curriculum) to ensure that all students acquire the knowledge, skills, and dispositions to meet sustainability challenges; and 5) Lead the assessment and reporting of metrics of sustainably in higher education for the purpose of driving improvements in sustainable practices and education through its Sustainability Tracking, Assessment and Rating System.

\section{F. Taiwan Sustainable Campus Project}

Taiwan Sustainable Campus project (TSCP) developed by an Advisory Committee including researchers and experts of multi-disciplines and organized by Ministry of education in Taiwan. It initiates the basic guidelines, simultaneously provided the available support related to knowledge, skills, and technology; further more to execute essential supervision and evaluation regarding sustainable development during the exercise of such a nationwide undertaking. It was developed to encourage schools adopt a self-examination and self-reflection by all members acting involved as the key role and mapping assessment in each campus performance. Besides, it expected not only to be a learning space but also a healthy, safe, and sustainable quality for the decades [12].

TSCP consists of a crucial component in this project while conducting in each campus. It encouraged a bottom-up networking model to be a crucial foundation for supporting in term of "sustainable campus" in the future. Meanwhile, the green school partnership project leads school to reconsider the campus from such as water energy saving appliance, recycling and reuse system, multi-layer green for $\mathrm{CO}^{2}$ reduction and biodiversity, permeable ground surface, artificial wetland, compost from foliage and kitchen waste, educational organic farm or eco-pond, and other impacts [12].

In sum, sustainable development deemed to as an international model within the current trend in higher education. It is an emerging issue, reminding administrators that the essence of higher education institutions is to provide for the future.

\section{Sustainable EduCATIONAL InSTITUTIONS}

Regarding sustainable educational institutions based on the definition of sustainable development in worldwide declaration, action, plan, or projects showed in the previous section, it is extraordinarily clear that sustainable development is a target which the human being pursues the higher amenity environment toward the future. Within the US, there are many organizations that comply with the United Nations' statements. The statements related to encourage universities engage in education, research, policy formation, and information exchange conduct on population, environment, and development move toward global sustainability.

Based on these facts, universities engages in global issue concerning sustainability, the critical dimensions of sustainability in higher education institutes presented some organizations such as the Association of University Leaders for a Sustainable Future (ULSF) resulted to Sustainability Indicators Project. Thereafter it is crucial to know the conditions in determining the success of sustainability initiatives. Several university efforts to green their institutions described these dimensions and conditions are crucial for success [4].

A total 430 and more university presidents and chancellors signed the Talloires Declaration representing the institutions from over 40 countries across five continents. Signatories clearly divided into developed countries and undeveloped counties and demonstrate colleges and universities, large size and small size, public and private. This shows the increasing recognition that academic research, teaching, and service must emphasize the sustainability challenge. However, facing the challenge on population, environment, and development issue, the educational institutes no doubt play a key role enhances progress toward sustainability.

In the understanding of words related to sustainability, going green or green building are coming up more frequently discussed in management of resources and regular business practices. The concept has also been discussed around for decades. However, it consists of the following principal components are protecting and restoring environmental systems, improving economic efficiency, and enhancing the well benefits of all peoples. A sustainable education institutes should involve campus program advocates all of these 
components. Sustainable initiatives must simultaneously consider for all of this impact. Hence, the current study organizes a series of initiatives shown in Table I.

TABLE I: INITIATIVES IN ATTAINING SUSTAINABLE INSTITUTIONS

\begin{tabular}{|c|c|}
\hline Initiatives & References \\
\hline $\begin{array}{l}\text { Sustainable development and sustainability have } \\
\text { become increasingly popular though amorphous } \\
\text { concepts over the last few decades, and many } \\
\text { governments, corporations and institutions are } \\
\text { adopting it as policy. }\end{array}$ & $\begin{array}{l}\text { United Nations } \\
\text { Division for } \\
\text { Sustainable } \\
\text { Development [13] }\end{array}$ \\
\hline $\begin{array}{l}\text { During this Rio+20 side event, leaders of the } \\
\text { international academic community will come } \\
\text { together to announce a new Higher Education } \\
\text { Initiative for Sustainable Development. The } \\
\text { initiative will be facilitated by an umbrella of } \\
\text { United Nations partner organizations. }\end{array}$ & $\begin{array}{l}\text { Launch of a Higher } \\
\text { Education Initiative } \\
\text { for Sustainable } \\
\text { Development [14] }\end{array}$ \\
\hline $\begin{array}{l}\text { Under the leadership of the United Nations } \\
\text { Economic Commission for Europe (UNECE), a } \\
\text { Regional Strategy was prepared to facilitate the } \\
\text { introduction and promotion of Education for } \\
\text { Sustainable Development. }\end{array}$ & $\begin{array}{l}\text { Education for } \\
\text { Sustainable } \\
\text { Development, } \\
\text { Europe and North } \\
\text { America [15] }\end{array}$ \\
\hline $\begin{array}{l}\text { The Asia-Pacific DESD Regional Launch in } \\
\text { Nagoya, Japan, in June 2005. UNESCO Bangkok } \\
\text { facilitated the drafting and finalization of the } \\
\text { strategy, based on the results of a regional ESD } \\
\text { situational analysis. }\end{array}$ & $\begin{array}{l}\text { Education for } \\
\text { Sustainable } \\
\text { Development, Asia } \\
\text { and Pacific [16] }\end{array}$ \\
\hline $\begin{array}{l}\text { In } 2002 \text {, the National Science Council sponsored a } \\
\text { research project titled "Green University } \\
\text { Evaluation Index System," which set out to } \\
\text { develop a system for evaluating the sustainability } \\
\text { performance of Taiwanese universities. That was } \\
\text { the first time the issue of campus sustainability in } \\
\text { higher education was raised in Taiwan. }\end{array}$ & $\begin{array}{l}\text { Green University in } \\
\text { Taiwan, Ministry of } \\
\text { Education }\end{array}$ \\
\hline
\end{tabular}

\section{A. The UN Division for Sustainable Development Relative Initiatives for Sustainable Educational Institutions}

The UN Division for Sustainable Development (UNDSD) is a part of the United Nations Department of Economic and Social Affairs; it located in New York of United States. The mission of Division is to promote sustainable development as the respective secretariat under the UN Commission on Sustainable Development (CSD) and conduct variety cooperation and to share capacity of building experiment at the area, regional and national levels [13].

In United Nations Agenda 21 recognized that extends public participation is one of the fundamental essentials to reach sustainable development, it identifies key roles as prerequisites for nine leading groups concerning civil society. The group includes women, children and youth, indigenous people, and non-governmental organizations. These are like local authorities, workers and trade unions, business and industry. Based on these factors, it is obviously the Division encourages and supports the leading groups to the CSD process by means of participation and contribution and assists their interactive participation in official sessions of CSD [13]. Hence, higher education institutions obviously have a responsibility to meet the target of the human being pursues the higher amenity environment toward the future. Simultaneously acts a particularly crucial role to improve economic more efficiency, protecting and restoring ecological environment. It demonstrated as above mentioned, institutes enhancing the amenity environment of the peoples related to the organization, and communities.

\section{B. The UN Educational, Scientific and Cultural Organization Relative Initiatives for Sustainable Educational Institutions}

The UN Educational, Scientific, and Cultural Organization (UNESCO) are the chief agency for the UN. It published the Decade of Education for Sustainable Development (2005-2014) stated the direction of economic and social affairs. The holistic events organized by UN Department of Economic and Social Affairs (UNDESA) on behalf of UNESCO, UN Academic Impact, UN University, and UN Global Compact [14]. Since higher educational institutes conduct the educated and training decision makers, they play a key role in processing more sustainable societies and developing new paradigms. The initiative had appealed those chiefs and leaders of the academic community around the world to engage and nourish research and teaching regarding sustainable development issues [14].

Aim to the human history and the well-being of countries were so closely associated with the environmental quality and outreach courses of higher educational systems and institutes in World Conference on Higher Education Partners, June 2003, the organization presents the creation to meet educational needs and examines strategies of improving higher education opportunities [14]. Based on these points, it is evident that the perception of environmental quality is crucial. However, UNESCO contribute to promote policies enhance quality education and research field in educational institutes is significant.

\section{Europe and North America Relative Initiatives for Sustainable Educational Institutions}

The leadership of the United Nations Economic Commission for Europe (UNECE) developed a regional strategy to assist the promotion of education sustainable development (ESD). The Strategy developed at the UNECE in Lithuania as well creates the Decade of Education for Sustainable Development (DESD) in the region on March 2005. It led to ESD emphasizes the political agenda likewise developing structures and provisions for ESD in the region. However, the main topic of sustainable development in the region including poverty alleviation, responsibility, citizenship, ethics, peace in the region and global contexts, it is necessary to closely associate region and networks working on ESD [15].

Based on the other parts concern to health, gender equity, democracy and governance, human rights, justice, security, cultural diversity, and economy; nevertheless, it demonstrates the rural and urban development, production and consumption patterns, and environmental protection. Thus, topics of ESD are no doubt varying from nation to the nation in the future. In general, the region has increasingly focused on the environment, nature, and ecology even discussed the human right, justice, and cultural diversity rather than the aspect of social and economic related to sustainable development [15].

In North America including United States and Canada, a considerable challenge as well identified in the region. Both of the countries strive to generate the level of stakeholder competences to implement ESD programs against the challenge. With respect to the emerging challenges includes the lack of an accordant with ESD missions, researchers and 
organizations explored the bewilderment regarding the differences between environmental education and ESD. Thereafter create and develop the strategic frameworks to integrate ESD including appropriate ESD concerning teaching tools and research assessment [15].

\section{Asia and the Pacific Relative Initiatives for Sustainable Educational Institutions}

The regional Decade of Education for Sustainable Development (DESD) conducts strategies in the Asia-Pacific region early demonstrated at the Asia-Pacific DESD Regional initiate in Nagoya, Japan, in June 2005. The United Nations Educational, Scientific and Cultural Organization (UNESCO) at Bangkok likewise assisted the drafting process and finalized the strategy to achieve the results of a regional ESD phase analysis. It considered that sustainable development is adaptable for revisiting base on the multiple needs of stakeholders and emerging issues in Asia and the Pacific [16].

Besides, a Pacific ESD Framework in the Pacific region initiate to serve as the coordinating association for the practice of ESD accredited by the Pacific Education Ministers Meeting in Nadi, Fiji, on September 2006. It conducts a coordinated and collaborative action to reach the vision of sustainable development. The challenges in the Asia-Pacific region deemed to include political and economic crises as natural disasters. Hence, Asia-Pacific nations are striving to build clear sustainable development priorities to assist and consider investment and effort to conduct curriculum development and implementation evaluation [16].

\section{E. Taiwan MOE Relative Initiatives for Sustainable Educational Institutions}

The Ministry of Education began to promote environmental education in primary and secondary schools concerning "Green Schools" and "Sustainable Schools" programs in late 1990. Thereafter the Ministry of Education paid a little attention to campus sustainability in colleges and universities. The National Kaohsiung Normal University in Taiwan held the first international green university workshop to promote in term of campus sustainability in higher education and signed the Talloires Declaration in 2004. In December 2007, the Ministry of Education persuaded to sponsor a program to promote green university event.

In addition, earlier of that year on World Environment Day, the Ministry of Education attempt to implement the carbon reduction policy, promote the practice of green campus that the Green University Project (GUP) initiated. Moreover, the government establishes baseline data for further research, such as the development a green university accreditation system by means of the GUP to raise awareness among universities. It also expects to help universities and college reach to the theme of Education for Sustainable Development (ESD).

\section{CONCLUSION}

This study adapted the assessment framework and expects to explore the evaluation system related to higher education institutions green university indicators; it also expects that it can provide as a starting point for future research studies.

\section{REFERENCES}

[1] D. Kuo. (2009). Campuses Warm to Tackling Conservation Challenge. [Online]. Available: http://www.chinapost.com.tw/taiwan/local/taoyuan/2009/12/30/23856 4/Campuses-warm.htm

[2] P. Brown and H. Lauder, "Education, globalization and economic development," Journal of Education Policy, vol. 11, no. 1, pp. 1-25, 1996.

[3] World Commission on Environment and Development (WCED), Our Common Future, Oxford, NY: Oxford University Press, 1987.

[4] R. M. Clugston, "Agenda for action," Theology and Public Policy, vol. 8, no. 1-2, pp. 101-111, 1996.

[5] The United Nations Educational, Scientific and Cultural Organization (UNESCO), The UN Decade of Education for Sustainable Development, Draft International Implementation Scheme, Paris, 2005 .

[6] BCR, The Report of the World Commission on Environment and Development, The Brundtland Commission Report - Our Common Future, Washington, DC: United Nation, 1987.

[7] University Leaders for a Sustainable Future (ULSF). (1990). Talloires 10 Action Plan. [Online]. Available: http://www.ulsf.org/talloires_declaration.html

[8] Halifax Declaration. (1991). Halifax Action Plan for Universities of the conference on Creating a Common Future. [Online]. Available: http://www.iisd.org/educate/declarat/halifax.htm

[9] Association of University Leaders for a Sustainable Future (ULSF), University and College Sustainability Websites. (2008). [Online]. Available: http://www.ulsf.org/resources_campus_sites.htm\#can

[10] L. Matson, J. Dautremont-Smith, D. Newport, and J. Walton, "Sustainability tracking, assessment and rating system for colleges and universities," STARS, 2008.

[11] AASHE, "The Association for the advancement of sustainability in higher education," AASHE Mission, Vision and Goals, 2012.

[12] TSCP. (2012). Taiwan Sustainable Campus Project Development. [Online]. http://140.135.10.180/esdtaiwan_english/intro.php

[13] UNDSD. (2005). The United Nations Division for Sustainable Development in brief. Selected Key Issues. [Online]. Available: http://www.un.org/esa/desa/aboutus/keyissues.html

[14] UNESCO. (2012). The United Nations Educational, Scientific and Cultural Organization. Higher Education Themes. [Online]. Available: http://www.unesco.org/new/en/education/themes/strengthening-educa tion-systems/higher-education/

[15] UNESCO. (2012). [Online]. Available http://www.unesco.org/new/en/education/themes/leading-the-internati onal-agenda/education-for-sustainable-development/around-the-world /europe-and-north-america/

[16] UNESCO. (2012)

[Online].

Available http://www.unesco.org/new/en/education/themes/leading-the-internati onal-agenda/education-for-sustainable-development/around-the-world /asia-and-the-pacific/

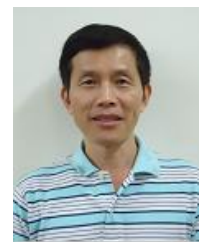

Wen-Sheng Wang is currently a PhD student at the National Central University, Taiwan. Regarding this study he acknowledges the support of Lunghwa University of Science and Technology through the learning, research, and administrative service that enable the success of this study. He also hopes that this study can help develop a sustainable ecological systems and educative practices for environmental awareness, local action, and global thinking as a major fundamental concept for future academe.

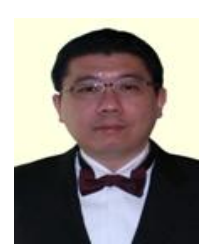

Gregory S. Ching received his $\mathrm{PhD}$ in education from the National ChengChi University, Taiwan, and he is currently an assistant professor at the Graduate School of Educational Leadership and Development in $\mathrm{Fu}$ Jen Catholic University, Taiwan. Dr. Gregory S. Ching's research interests include technology and education, globalization, higher education issues, international student mobility, and student engagement. 